\title{
高密度対応ビアフィルめっき技術の動向
}

\author{
小山田 仁 子*，本 間 英 夫** \\ *関東学院大学大学院 工学研究科（=236-8501 神奈川県横浜市金沢区六浦東 1-50-1） \\ **関東学院大学 工学部（干236-8501 神奈川県横浜市金沢区六浦東 1-50-1)
}

\section{The Trend of Via-Filling by Plating Technology for High-Density Packaging}

\author{
Kimiko OYAMADA* and Hideo HONMA**
}

\begin{abstract}
*Graduate School of Engineering, Kanto Gakuin University (1-50-1, Mutsuura-higashi, Kanazawa-ku, Yokohamashi, Kanagawa 236-8501)

**Faculty of Engineering, Kanto Gakuin University (1-50-1, Mutsuura-higashi, Kanazawa-ku, Yokohama-shi, Kanagawa 236-8501)
\end{abstract}

Key Words: Via-Filling, Copper Electroplating, Damascene Process, Three-Dimensional Integration Technology

\section{1.はじめに}

近年の電子機器の小型化・高性能化によって，搭載される 半導体素子の高密度化・高集積化が要求されている。特に, IT 革命によるユビキタス時代の到来とともにネットワーク のブロードバンド化や無線通信の急速な普及にともなう，携 帯電話やPDA などのモバイル機器のさらなる機能向上が早 急に求められている。そのため, 電子機器の中心的な役割を 果たす半導体関連技術と, 半導体素子を搭載するプリント配 線板の製造技術および実装技術に注目が集まっている。従来 から注目される配線板の製造法としてビルドアップ工法 ${ }^{1), 2}$ が挙げられるが, この工法は交互に積層された導体層と絶縁 層をブラインドビアによって層間接続するもので, ビア内部 は導電膜形成後に絶縁樹脂や導電性ペーストにて充填されて きだ)。しかしながら, 配線の接続信頼性向上および通信速 度の高速化の進展にともない，ビア内を銅にて充填するビア フィリングが盛んに検討されるようになってきた。また最近, 各層間のビアを銅で充填し垂直に積層するスタックビア4)構 造が検討されている。このように，銅めつきによるビアフィ リングに関して数多くの研究が報告されている ${ }^{5) \sim 7) 。 ら に, ~}$ プリント配線板に搭載される半導体も高密度化が進んでいる。 半導体の性能向上を予測する際の指標として広く用いられて いるのがムーアの法則であるが, この法則は, 米 Intel 社の 設立者の一人ゴードン・ムーアが 1965 年に提唱したもので ありあまりにも有名である。実際には集積密度の向上ペース はこの数年鈍化してきているが「集積密度」を「性能向上」 に置き換えて考えると，この法則は現在でも成立していると される。またこの「ムーアの法則」がその存在意義を確固た るものとしたのは 1997 年 IBM から発表されたダマシンプ ロセスであり ${ }^{8)}$ これは硫酸銅めっきと CMP (Chemical Mechanical Polishing) 技術を組み合わせた銅配線デバイス である。従来から用いられてきたアルミニウム合金配線から 銅配線へ移行するという, このプロセスの確立は半導体配線
の技術的な限界を乗り越え, さらなる可能性を飛躍させただ けでなく，これまで乾式法による金属成膜技術が主流であっ た業界内に湿式法を取り入れる大きな契機となった。また， 次世代実装技術として SIP (System In Package)が注目され ている。SIP とは, 複数の LSI を単一のパッケージに封止 してシステム化を実現した 3 次元実装技術であり, 低電力 化・高性能化・実装面積削減という利点がある ${ }^{91}$ 11)。この技 術は, チップをインターポーザと呼ばれる超薄型で小型な支 持物に固定し，これらを複数個組み合わせてシステムを 1 つ のパッケージ内に収めるものである。それ故実装面積縮小化 の観念から垂直方向への積層が望ましい。したがって, それ らを最短距離で接続するために積層貫通配線が必要である。 本稿ではこれら配線形成技術に使用されるビアフィリング について解説する。

\section{2. プリント配線板製造におけるビアフィリング}

電子機器の飛躍的な小型化・高性能化にともないプリント 配線板は従来のスルーホール基板から, 導体層と絶縁層を交 互に積層しブラインドビアと呼ばれる微小穴を用いて層間接 続を行うビルドアップ工法へと移行してきた。従来はブライ ンドビア内を電気銅めつきにより導電化後, 絶縁樹脂や導電 性ペーストを充填してきたが, さらなる高密度化・高速化に 対応するためブラインドビア内を金属銅で充填するいわゆる ビアフィリングが検討されてきた。最近では各層間のビア フィリングしたブラインドビアを垂直に積層し, スタックビ ア構造にする試みが行われており配線の大幅な高密度化・高 速化が期待できる。

これまで, 無電解めっき, 直流電解法, パルス電解法, お よび PR (Periodical Reverse)電解法によるビアフィリング について検討され, 無電解めつきおよび PR 電解法により

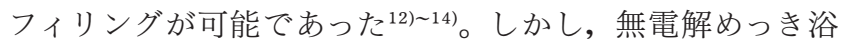
は強アルカリ性であり, しかも処理時間が長いため材料に夕゙ メージを与える。一方, PR 電解法では, 周期的に析出と溶 

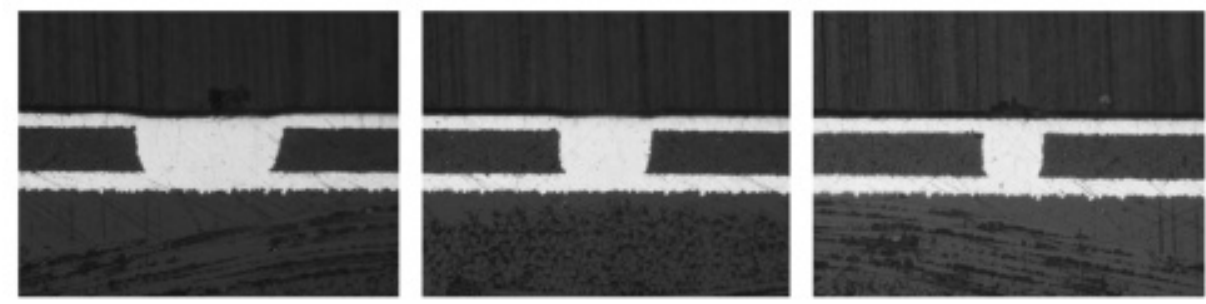

$100 \mu \mathrm{m}$

図 1 プリント配線板製造におけるビアフィリング
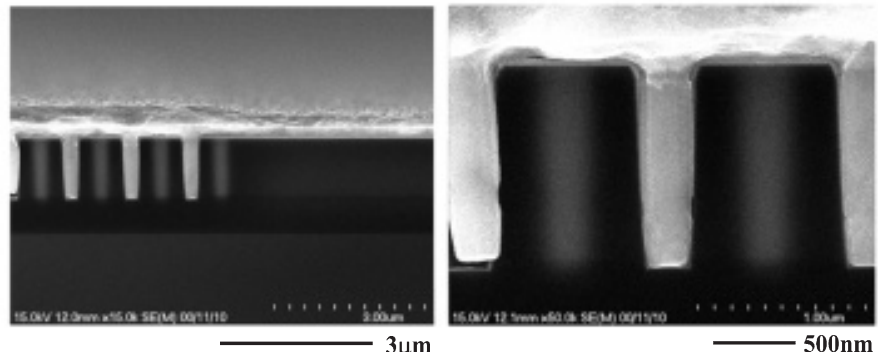

図 2 半導体配線形成におけるビアフィリング

解を繰り返すので析出皮膜の表面状態が粗く, めつき時間が 長くなるなどの問題があった。最近では, 直流電解法を用い て硫酸銅めつき浴中の添加剤を制御することにより, 図 1 に 示すようにビア内部を完全に充填する方法が主流になってき た ${ }^{15), 16)}$ 。

硫酸銅めつき浴には一般に装飾めっき用として使用される 銅濃度の高い一般浴，およびプリント配線板のスルーホール めつきに代表される銅濃度の低いハイスロー浴がある。また, 添加剤には主にキャリヤー, ブライトナー, レベラーと呼ば れる有機化合物が添加される。一般に, キャリヤーには PEG (Polyethylene Glycol)に代表されるようなノニオン系 界面活性剤であるポリエーテル化合物が使用され, 濡れ性を 改善すると同時に濃度の増加にともなって, 非常に大きな分 極作用を示す分極剤である。また PEG と同様に, 一般に塩 素イオンがアノードの溶解を補助しアノード上に酸化銅およ び亜酸化銅のスライム発生を防ぐために添加されているが, この塩素イオンは PEGの共存下で銅 ( I ) イオンと錯体を形 成し, 吸着には塩素イオンを介して金属表面に吸着し銅析出

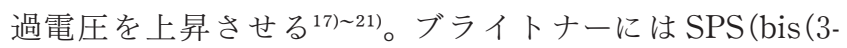
sulfopropyl) disulfide)のようなスルホン基を有する有機硫 化物が使用される。SPS は従来, 表面の光沢性向上のため に使用されてきたが, ビアフィリングでは復極効果によるビ ア底部での銅電析出促進作用により，埋め込みを改善する効 果があると考えられる ${ }^{22)}$ 。また，レベラーには窒素化合物で あるチオ尿素や, フェナジン系染料であるJGB(Janus Green B), ポリアミン誘導体などが挙げられる ${ }^{5), 23)}$ 。JGB においては，拡散支配となり流体力学的な影響を大きく受け るビアホールコーナー部ほど多量に吸着が進行し, 析出を抑 制し，また基板表面皮膜の光沢性を向上させると考えられ る ${ }^{19)}$ 。実際にはこれらの三成分の添加剤を用いてビアフィリ ングが実施されている。

\section{3. 半導体配線形成におけるビアフィリング}

従来, 半導体配線には PVD 法 (Physical Vapor Deposition)や CVD 法 (Chemical Vapor Deposition)によるドライ プロセスを用いたアルミニウム合金皮膜が使用されてきた。 しかし, 近年の電子機器の小型軽量化・高性能化にともない, さらなる配線の微細化, 高アスペクト比化が求められるよう になり，アルミニウムよりも比抵抗が低く，エレクトロマイ グレーション耐性に優れた銅が注目されるようになった。ま た, 1997 年 9 月 IBM の電気銅めっきと CMP (Chemical Mechanical Polishing) 技術を組み合わせたダマシンプロセ ス (Damascene process)を用いた銅配線デバイスの発表を契 機に，配線に銅を使用する技術が盛んに行われるようになっ

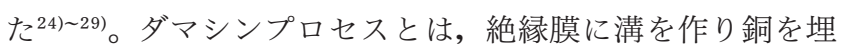
め込んだのち, CMP で表面の平坦化と配線形成を同時に行 う方法で, スパッ夕法, CVD 法, めっき法が用いられてい る。スパッ夕法においては成膜速度が速く良好な皮膜が得ら れるが, アスペクト比が 1 ～1.5 程度で均一な銅皮膜を得る には限界があり，また CVD 法では高アスペクト比でも埋め 込むことは可能であるが, 装置や原料のコストが高く成膜速 度が遅いという欠点がある。一方, めっき法はこれらの方法 と比ベコストが比較的安価であり, 成膜速度も速く良好な皮 膜が得られやすい。現在, 配線はさらなる微細化が進行して 抢り，アスペクト比も年々高くなってきていることから，電 気銅めっきでこの種の微細回路を形成する場合，めっき液に 種々の添加剤を加えることにより銅析出を制御し埋め込み性 を向上させている。一般には, トレンチやビアの埋め込みに 関して，めつき液および添加剤ともプリント配線板に使用さ れるものとほぼ同じものが使用されており, 添加剤濃度およ び電流密度を制御することにより，図２に示すように良好な フィリング性を得ている。このような配線の場合, テーパ構 造を有しないストレートホールであるため, 底部ボイドや 

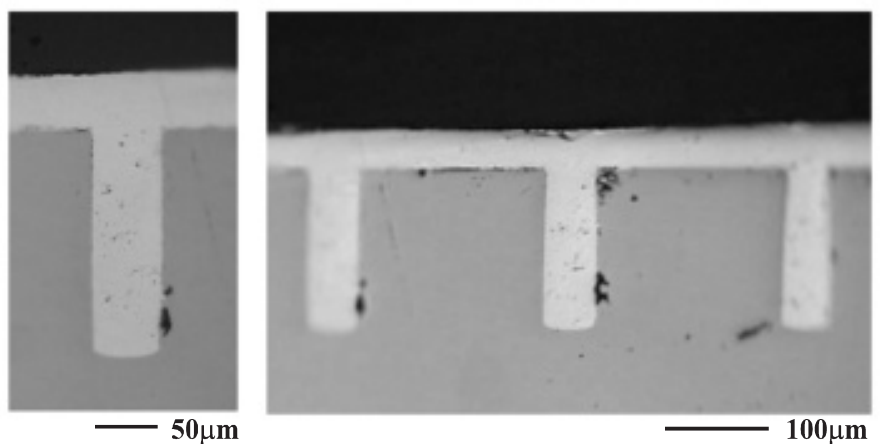

図 3 三次元実装技術への適応

シームなどの内部欠陥が起きやすく注意しなければならない。 また最近では，配線の微細化に対応すべく，無電解めつきを 用いてフィリングを行う手法についても検討されている30),31)。

\section{4. 三次元実装技術への適応}

近年のネットワークのブロードバンド化や無線通信の急速 な普及にともない，携帯電話や携帯情報端末，サーバなどの さらなる機能向上が課題となっており，搭載される LSI 内 外のデー夕転送速度の格差や, システムレベルの小型化の要 求に対し, 従来技術では対応が困難となっている。したがっ てこれらの問題を打開する新しい技術として SIP(System In Package) が注目されている。SIP とは, 複数の LSI や受動 部品をシリコン基板上に配置し，それらを単一のパッケージ に封止してシステム化を実現する 3 次元実装技術であり，現 在，複数のチップ間を接続する方法にはワイヤボンディング が挙げられるが, 配線密度や伝送速度などの問題から積層貫 通配線が検討されている。

上記で述べたように，シリコンウエハー上での銅配線形成 としてダマシンプロセスについては, 数多くの検討がなされ てきた。これらはいずれも開口径が約 $90 \mathrm{~nm} \sim 1.0 \mu \mathrm{m}$,アス ペクト比が 1 ～10 位の微細配線形成を目的としているが， SIPのような三次元実装では開口径が 10〜 $50 \mu \mathrm{m}$ 深さ 70 150 $\mu \mathrm{m}$ 程度と比較的大きい。したがって, この高アス ペクト比構造を有するビアに対し完全な埋め込みを得るには, これまでに検討してきたビアホールの埋め込み条件よりも表 面およびコーナー部の析出をさらに強力に抑制し，底部から の析出を優先的に行うことが必要不可欠である。そこで，添 加剤の制御が重要であることが示唆されるが, 添加剤の作用 は濃度だけでなくめつきする電流密度にも依存する ${ }^{13)}$ 。ハル セル試験に扔いて, PEG を添加することにより, 無添加浴, SPS 添加浴および JGB 添加浴における傾向と異なり, 高電 流密度部ほど膜厚が減少する傾向を確認した。これは, 高電 流密度部で銅析出反応とともに PEG 分子が多量に吸着し, 実際の電流密度を減少させたことが考えられる。それはめつ き初期に短時間高電流密度通電するだけでも効果があるとい う知見を得ている ${ }^{32)}$ 。また，アスペクト比が高くなるにつれ て, 配線構造内部では銅イオン濃度が著しく低下し, 濃度過 電圧の差が大きくなることで底部ボイドが発生しやすくなる。 そこで，底部での析出性の改善を考慮し電解初期に短時間の 高電流通電後より低電流密度での電析が考えられるが, 低電
流密度にてめつきをすると, 埋め込みまでには長時間を要す ることになる。しかし, 低電流密度で底部の析出が優先的に 起こるので，ビア部のアスペクト比は徐々に低下していくこ とになる。したがって, アスペクト比が小さくなれば電流密 度を上げることが可能であり, 段階的に電流密度を上昇させ れば成膜時間の短縮にもつながる。このような作用を利用し， 電流波形制御33),34) を行うことにより，図３に示すような フィリング状態が得られる34)。

\section{5. ビアフィリングの課題}

今まで, さまざまな形状のビアフィリングについて添加剤 の種類 (ブライトナー, キャリヤー, レベラー) 拈よび添加濃 度を制御することによりフィリングが可能であることを述べ た。しかしながら, 現状では電解時間の経過とともに添加剤 の効果が弱まり, ビア内を完全に銅で充填することは困難に なる。特にブラインドビアなど大きい形状のものほどそれは 顕著に現れる。そこで, 長期間電解による添加剤の消耗およ び分解の影響について，ブラインドビアの埋め込み性および 電気化学測定から評価した ${ }^{35)}$ 。その結果, フィリング率は 徐々に減少するのではなく，急激に低下する傾向がみられた。 この現象を個々の添加剤について詳細に調べたところ, PEG や JGB の効果は持続するのに対し, SPS の場合, 埋 め込み性は短時間で低下し皮膜はコンフォーマル状態に析出 した。これは, SPSの特徵である復極効果が, 電析中に急 激に低下したことが原因ではないかと考えられる。実際, 電 気化学測定によると電解時間が経過するとともに, 分極曲線 が卑方向へシフトしていることを確認した。それは, 経時的 に復極効果が減少していることを示唆している。SPS はビ アフィリングに対して優れた添加剤であるが，還元反応によ り MPS (Mercato-propanesulfonic Acid)へ，その分子が分 解され ${ }^{36)}$ ，またこの分解は電解時だけでなく浴中に $\mathrm{Cu}^{+}$が 存在する場合は常に起きていると報告されている37)。CVS 測定の結果, SPS と同濃度では MPS の方が析出促進作用が 弱いことが考えられ，埋め込み性が低下した理由としては， SPS が電析中に MPS に分解することにより電気化学測定で は復極効果を示すものの, 埋め込み性が低下したと考えられ る $^{35)}$ 。

\section{6.おわりに}

これまでは, マイクロからナノ領域の金属成膜方法として 
乾式法が主流であった。しかしながら，以上述べてきたよう に実装を中心とした導体膜形成が，高密度化・ファイン化に ともない乾式法では成膜速度が遅く，したがって超微細孔に 代表される高アスペクトの溝や孔への成膜が困難となり，湿 式法の代表であるめっき法が，にわかに注目されるように なってきた。今後は電子機器を初めとし, マイクロからナ, 領域の成膜技術としてめっき技術は益々重要になってくるで あろう。

(2004-8-31 受理)

\section{文献}

1）塚田＼cjkstart裕；回路実装学会誌，11，306（1996）

2 ）本多 進 ; 回路実装学会誌, 11，462（1996）

3 ）高崎義徳；回路実装学会誌，11，472（1996）

4 ）塚田 裕; 回路実装学会誌, 13, 2 (1998)

5 ) 松浪卓史, 伊藤智子, 岩本由香, 大和 茂; エレクトロニクス実 装学会誌, 4, 7 (2001)

6 ）若林信一, 中澤 清, 金子紀男; エレクトロニクス実装学会誌, 39, 12 (2000)

7 ）近藤和夫, 山川統広, 田中善之助, 間野和美 ; エレクトロニク 又実装学会誌, 4, 1 (2001)

8 ) P. C. Andricacos, C. Uzoh, J. O. Dukovic, J. Horkans and H. Deligianni；IBM J. Res. \& Devel., 42, 567 (1998)

9 ）桜井貴康；表面技術, 53, 224（2002）

10）栗野浩之, 小柳光正；表面技術，53，228（2002）

11）若林 猛；表面技術, 53, 233 (2002)

12）阿部真二, 藤波知之，青野隆之，本間英夫 ; 表面技術, 48, 433 (1997)

13）藤波知之, 小林 健, 真庭朝夫, 本間英夫 ; 表面技術, 48, 660 (1997)

14) S.-C. Kou and A. Hung ; Plating \& Surface Finishing, May (2000)

15）小林 健, 川崎淳一, 三原邦昭, 山下嗣人, 本間英夫 ; エレクト ロニクス実装学会誌, 3, 4（2000）

16）三浦修平, 三原邦明, 福士 司, 本間英夫 ; エレクトロニクス 実装学会誌, 5, 3 (2002)

17) M. Yokoi, S. Konishi and T. Hayashi ; DENKI KAGAKU, 52, 4 (1984)

18) J. J. Kelly and A. C. West ; J. Electrochem. Soc., 145, (10)
(1998)

19）高田祐一, 小山田仁子, 三浦修平, 本間英夫 ; エレクトロニク 又実装学会誌, 4, 219 (2001)

20) J. J. Kelly and A. C. West ; J. Electrochem. Soc., 145, (10) (1998)

21) T. P. Moffat, D. Wheeler and D. Josell ; J. Electrochem. Soc., 151, (4) (2004)

22) S. Miura, K. Oyamada, Y. Takada and H. Honma ; Electrochemistry, 69, 10 (2001)

23) J. J. Kelly, C. Tian and A. C. West ; J. Electrochem. Soc., 146, (7) (1999)

24）上野和良；表面技術，49，11（1998）

25）縄舟秀美；表面技術，49，11（1998）

26) V. S. Donepudi, R. Venkatachalapathy, P. O. Ozemoyah, C. S. Johnson and J. Prakash ; Electrochem. \& Solid-State Lett., 4, C 13 (2001)

27) P. Taephaisitphongse, Y. Cao and A. C. West ; J. Electrochem. Soc., 148, C 492 (2001)

28) M. Georgiadou, D. Veyret, R. L. Sani and R. C. Alkire ; J. Electrochem. Soc., 148, C 54 (2001)

29) H. Nawafune, H. Kitamura, S. Mizumoto, E. Uchida and T. Okada ; Hyomen Gijyutsu, 51 (2000)

30) T. P. Moffat, J. E. Bonevich, W. H. Huber, A. Stanishevsky, D. R. Kelly, G. R. Stafford and D. Josell ; J. Electrochem. Soc., 147 (2000)

31) S. Shingubara, Z. Wang, O. Yaegashi, R. Obara, H. Sakae and T. Takahagi; Electrochem. \& Solid-State Lett., 7, (6), C 78 (2004)

32）小山田仁子, 秋山未来, 西中山宏, 三浦修平, 本間英夫 ; エレク トロニクス実装学誌, 6, 3 (2003)

33）小林 健, 川崎淳一, 石橋純一, 田中健太郎, 本間英夫 ; 表面技 術, 49, 1332 (1997)

34）小山田仁子, 渡邊新吾, 西中山宏, 本間英夫 ; 表面技術, 54, 8 (2003)

35）小山田仁子, 西中山宏, 渡邊新吾, 本間英夫 ; エレクトロニク 又実装学会誌, 7, 3 (2004)

36) E. E. Farnndon, F. C. Walsh and S. A. Campbell ; J. Applied Electrochemistry, 25 (1995)

37）松浪卓史, 掛橋一能, 大和 茂, 吉田直人 ; 第 17 回エレクトロ ニクス実装学術講演大会要旨集, p. 11 (2003) 